\title{
Celltech acquisition sends mixed messages
}

The $\mathfrak{E} 1.53$ ( $\$ 2.25$ ) billion agreed-on acquisition of the UK's eldest biotech company, Celltech, by the little-known Belgian drug company UCB on May 18 provides a warning that independent European biotechnology firms may never be able to rival US giants such as the Californian companies Amgen and Genentech. On the upside, the deal could herald a rash of similar cross-border mergers that may be needed to restructure the industry in Europe so that it can compete with global players.

Celltech, in London, is Britain's largest independent biotechnology company, with 2003 revenues of $\mathfrak{E 3 5 3}$ (\$641) million and operating profits of $\mathfrak{E 5 0}$ (\$91) million. The company's size and its apparent maturity were clearly attractions for UCB, a mid-sized pharmaceutical manufacturer in Brussels best known for its blockbuster antihistamine drug Zyrtec. The UCB takeover is regarded in many quarters as a real setback for the UK biotechnology sector. Sally Bennett, vice president of biotechnology equity research at investment bank ING Financial Markets in London, adds that it may well affect investors' sentiment towards the sector.

One of the principal drivers behind the UCB bid, investment analysts say, is undoubtedly Celltech's late-stage product pipeline. The company has an extremely promising compound, CDP870, that is well into clinical trials both for Crohn's disease (due to launch in 2006) and for rheumatoid arthritis (scheduled for launch in 2007). Analysts estimate CDP870's sales could reach $\$ 740$ million by 2010 .

Before the UCB acquisition, Celltech had been looking for a new development and marketing partner for CDP870 ever since it lost its previous backer Pfizer in late 2003, in the wake of the Pharmacia merger. Pharma giants GlaxoSmithKline, in London, and Aventis, in Strasbourg, France, are both known to have considered in-licensing the product, and Cambridge, Massachusettsbased Biogen-Idec is also thought to have expressed interest in the company. According to Celltech, UCB was able to come up with terms that are equivalent to those of the
Pfizer deal in terms of net present value. With 2003 sales of $€ 3$ (\$4.4) billion, UCB has thrown its significant weight behind the project as part of a new corporate focus on biopharmaceuticals and away from its chemical activities.

The puzzle is: having found a new partner, why did Celltech not choose to remain independent? According to Bennett, Celltech's motive was probably that its earlier-stage products would also have had to be partnered at some point and this deal is a way for investors to retain more value at a later stage. Another possibility is that the offer was part of the negotiating position taken by UCB when closing the licensing deal, says Alain Gilbert, an associate at the biopharmaceutical advisory services firm Bionest Partners in Paris.

"One thing [the] Celltech [acquisition] definitely shows is that biotech company valuations are way too low, far below the real value in UK biotechnology," remarks Aisling Burnand, chief executive of the UK Bioindustry Association. That allowed UCB to buy a very good company quite cheaply, she says. Other obvious UK-based undervalued candidates for acquisition are speciality pharmaceutical development company Alizyme in Cambridge, vaccines firm Acambis in Cambridge, anticancer biopharmaceutical company Antisoma in London and possibly therapeutic antibody developer Cambridge Antibody Technology.

By contrast, the larger mainland European biotechs, such as Basel-based Actelion and Qiagen in Venlo, The Netherlands, tend to be priced closer to their real value, although one or two, such as Zeltia in Madrid and Genmab in Copenhagen, are trading at discounts that may look attractive to bidders.

Another view of the Celltech acquisition is the emerging consensus that if European biotech firms are ever to grow big enough to challenge US dominance, they must cross national borders. National fragmentation is a main reason European companies have not succeeded in growing to the same degree as US companies, according to Bennett. "Each individual country in Europe has its local

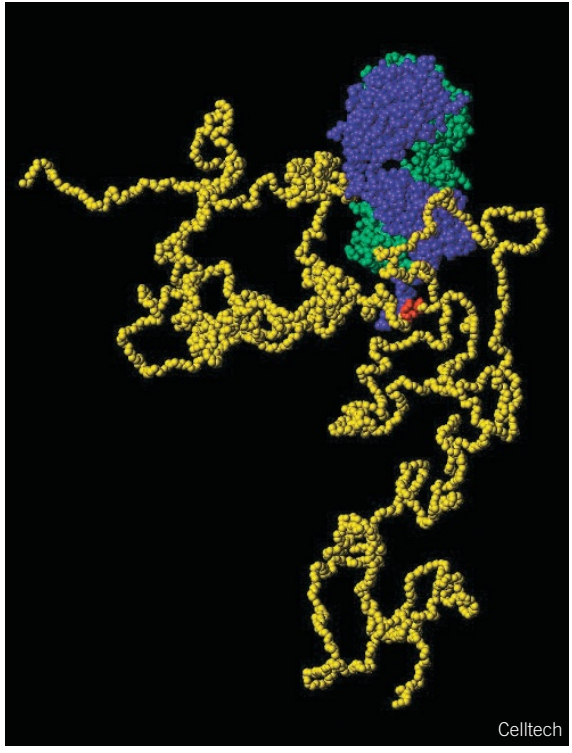

CDP 870, Celltech's most promising product, attracted UCB to acquire the company.

investors who like to invest in local companies with local management, and that needs to change," she says. "This deal emphasizes that even Celltech, one of the larger biotech companies in Europe, believes that it needs to merge with a bigger group to get the critical mass needed to deliver shareholder value," she adds.

So mergers appear to be the way forward for the moment. Moreover, Johan Vanhemelrijck, secretary-general of the European biotechnology trade association EuropaBio, points out that this consolidation can happen only if cross-border mergers become more common. But will these buyers typically come from elsewhere in Europe, as with Celltech? Unlikely, says Alan Kingsman, chief executive of another long-established independent, UK biotech Oxford Biomedica. "Most of us in Europe will still look to the US for mergers and acquisitions," he says. "There is more cash there and there are so many more advanced companies that are attractive partners for smaller biotech players. That won't [be] changing any time soon."

Peter Mitchell, London 